\title{
Gizli Alkol Tüketimi Üzerine Nitel Bir Araştırma: İzmir İli Örneği
}

\section{Dogan Basaran ${ }^{\mathrm{a}}$, Ayla Ozhan Dedeoglu}

Öz: Gizlilik, başkalarının bilmesini engellemek için bir bilginin sosyal ortamdan çıkarılması ya da sosyal ilgiyi bilgiden farklı yöne çekecek farklı bilginin eklenmesi, diğer bir ifadeyle bilginin maskelenmesi, şeklinde gerçekleşebilmektedir. Kişinin mahremiyetini korumak, sosyal ilgiden kaçınarak sosyal çevreye uyum sağlamak ve/veya ideal ve normatif benlik ile gerçek benlik arasındaki uyuşmazlıklarından kaçınmak amacıyla kullandığı gizliliğin tüketim pratiklerine yansıması ürünün özelliğine ve kültürel çevre bağlamına göre farklı gerçekleşebilmektedir. Mevcut çalışma, gizli tüketim olgusunu erdemsiz ürün olarak nitelenen alkollü içki tüketimi odağında incelemekte olup gizliliğin nedenleri, satın alma ve tüketim pratiklerinde nasıl deneyimlendiği ve tüketicinin davranışlarına etkilerini keşfetmek amacıyla gerçekleştirilmiştir. Nitel araştırma yöntemi ile gerçekleşen fenomenolojik çalışmanın örneklemi İzmir ilinde ikamet eden genç ve eğitimli gizli alkol tüketicileridir. Bulgular alkol tüketiminin, yoğunlukla yakın çevre ve aileden gizlendiğini ve tüketicilerin mahremiyetleri ve sosyal kimliklerini sürdürebilmek için minimum riski olanaklı kılacak çeşitli başa çıkma stratejileri kullandıklarını göstermektedir. Gizli alkol tüketiminin zihinsel bir meşguliyete yol açarak tüketimden alınan tatmini azalttığı bulunmuştur.

\section{A Qualitative Study on Secret Consumption of Alcoholic Beverages: The Case of Izmir}

Abstract: Secrecy is defined as an act of omission of information from a social environment or inclusion of other information to divert social attention by masking private information. Consumers may need secrecy to protect privacy, conform to the social environment without attracting unwanted attention, and/or avoid discrepancies between actual and ideal, and normative "ought" selves. Secret consumption experiences may differ based on product characteristics and social and cultural context. The present phenomenological study aims to explore the secret consumption of alcoholic beverages, which is described as a demerit good, and was carried out to find out the reasons for confidentiality, how it is experienced in purchasing and consumption practices, and its effects on consumer behavior. Qualitative data analysis was conducted using data collected from a sample of young and educated secret alcohol consumers residing in the province of Izmir. The findings show that participants keep their consumption secret from immediate environment and families. Consumers use various coping strategies that enable protecting their privacy and social identities, while maintaining their consumption at a minimum risk. It has been found that secret alcohol consumption leads to mental preoccupation and reduces satisfaction with consumption.
Anahtar Sözcükler: Gizli Tüketim, Alkollü Içecek Tüketimi, Sosyal Kimlik, Benlik Uyuşmazlığı, Zihnin Meşguliyeti

JEL: M31, H49

\begin{tabular}{|c|c|}
\hline Geliş & : 20 Eylül 2021 \\
\hline Düzeltme & : 08 Kasım 2021 \\
\hline Kabul & : 26 Kasım 2021 \\
\hline Tür & : Araştırma \\
\hline
\end{tabular}

Keywords: Secret Consumption, Consumption of Alcoholic Beverages, Social Identity, Self-Discrepancy, Preoccupation

JEL: M31, H49

Received : 20 September 2021 Revised : 08 November 2021 Accepted : 26 November 2021

Type : Research

a PhD Student, Ege Universtiy, Institute of Social Sciences, Marketing Programme, Izmir, Turkiye, doganbasaran@hotmail.com (ORCID ID: 0000-0002-4059-5171)

b Prof., PhD, Ege University, Faculty of Economics and Administrative Sciences, Department of Business Administration, Izmir, Turkiye, ayla.dedeoglu@ege.edu.tr (ORCID ID: 0000-0002-0179-0644) 


\section{Giriş}

Gündelik hayatta oldukça yaygın bir olgu olan gizlilik, kişinin bilinçli bir şekilde mevcut bilgiyi başkalarından saklama kararı ve çabasıdır (Kelly, 2002; Critcher ve Ferguson, 2014; Slepian, Chun ve Mason, 2017). Bazen eğlence amaçlı olarak bazen de olumsuz durum ve duygulardan kaçınmak için sır tutulabilmektedir. Gizliliğin doğasında sır tutucu ve sır tutulan olarak en az iki kişi yer almaktadır. Gizlilik, sosyal ortamdan bir bilginin çıkarılması ya da bazen de sosyal ilgiyi bilgiden farklı yöne çekecek farklı bilginin eklenmesi, diğer bir ifadeyle bilginin maskelenmesi, şeklinde gerçekleşebilmektedir. Gizlilik, kişinin mahremiyetini korumak ya da ötekilerin mahrem alana girişini engellemek amaçlarını taşıyabilmektedir.

Gizlilik, bir yandan sır taşıyanın fiziksel ve psikolojik iyi oluşunu etkileyebilirken diğer yandan sosyal çevre bağlantılarından, diğer bir ifadeyle sosyal ilgiden kaçınmasını da sağlamaktadır (Felmleei, 2001; Slepian vd., 2017). Sosyal ilgi aynı zamanda sırrın ifşası riskini yarattığından (Goodwin, 1992) insanlar gizliliği sağlamak için farklı stratejiler kullanmakta ve bu süreçte de saklı tutmak istedikleri düşüncelerini aktif olarak bastırmaya çalışmaktadırlar. Bu da konuyla zihinsel olarak aslında daha fazla meşgul olmalarına neden olabilmektedir (Lane ve Wegner, 1995).

Gerek mahremiyeti sağlama gerekse sosyal ilgiden kaçınarak sosyal çevreye uyum sağlama ve ideal veya normatif benlik ile gerçek benlik arasındaki uyuşmazlıktan kaçınma çabalarının yönlendirdiği gizliliğin tüketim pratiklerine yansıması ürünün özelliğine ve sosyal ve kültürel çevre bağlamına göre farklı gerçekleşebilmektedir. Pazarlama bağlamında da gizliliğe yönelik çeşitli çalışmalara olan ilgi giderek artmaktadır (Nicholas, Raska ve Flint, 2015; Thomas ve Jewell, 2019; Rodas ve John, 2020; Ker ve Kao, 2021). Rodas ve John (2020) gizliliği ürün tutum ve değerlendirmelerinde kutuplaştırıcı bir etkisi olduğunu ortaya koyarlarken Thomas ve Jewell (2019) gizli tüketim eylemine giren tüketicilerin benlikleri ve marka arasında daha güçlü marka bağlantı kuracaklarını savunmuşlardır

Erdemli ürün, tüketiminin olumlu algılandığı ve ekonomi politikaları ile üretim ve tüketiminin teşvik edildiği ürünler iken erdemsiz ürünler tüketiminde pozitif etkilerinin doğru şekilde tahmin edilememesi ve hatta negatif etkiler yaratabilmesi nedeniyle üretim ve tüketimi azaltılmak istenen, vergiler yoluyla kısıtlanan ya da yasaklanan ürünlerdir (Ver Eecke, 1998; Mann, 2006). Başında tütün mamulleri ve alkollü ürünlerin yer aldığı erdemsiz ürünler negatif dışsalığa sahip, toplumun sağlığını bozan mal ve hizmetlerdir (Balestrino, 2008).

Bu çalışma, muhafazakarlığın arttığı ve alkollü içeceklere karşı olumsuz tutumun yaygınlaştığı Türk toplumunda, bu ürünlerin gizli olarak tüketim eğilimine odaklanmaktadır. Gizli tüketim olgusunu erdemsiz olarak nitelenen alkollü içecek tüketimi odağında inceleyen bu araştırma ile keşfedilmek istenen alan, sosyal çevrenin gizli alkol tüketime etkisi, gizlemenin altında yatan tüketim motivasyonları ve gizli alkol tüketiminin satın alma ve tüketim pratiklerinde nasıl deneyimlendiği ve tüketicinin davranışlarına nasıl yansıdığı konularıdır. illk olarak gizliliğin ele alındığı bu çalışmada daha sonra sosyal kimlik ve gizli tüketim ilişkisi incelenmiştir. Nitel araştırma metodolojisi ile gerçekleştirilen araştırmada tüketicilerinin alkol tüketimlerini gizleme nedenleri, sırrın ifşasını engellemek amacıyla sosyal ilgiden kaçınmak için geliştirdikleri çeşitli stratejiler ve gizli alkol tüketiminin ürün değerlendirmesine olan etkilerini araştırılmıştır.

\section{Gizlilik}

Sır tutmak veya gizlilik, bir bilgiyi başkalarının bilmesini engellemek amacıyla bilinçli bir şekilde gizlemek ya da bilginin ifşanın aktif engellemektir (Larson ve Chastain, 1990; Margulis, 2003). Gizlilik gündelik hayatta sosyalleşme sürecinin kaçınılmaz çıktılarından (Kelly, 2002) olup hemen hemen herkes sır tutmaktadır (Slepian vd., 2017). Bazı insanlar eğlence amaçlı sır tutarlarken (Vrij, Paterson, Noonkosing, Soukara ve Oosterwege, 2003) (örn. sürpriz doğum günü partisi); bazılarıysa negatif sosyal ilgiden, utanç veya baskıdan kurtulmak için sır tutmaktadırlar (Goodwin, 1992; Krishna, Herd ve Aydınoğlu, 2019). Sosyal ilgiden kaçınma güdüsü bu noktada önem taşımaktadır. Çünkü sosyal ilgi, sosyal etkileşimi tetikleyerek gizliliği riske edip sırrın ifşasına yol açabilir. 
Her ne kadar sır tutmanın çeşitli motivasyonları olsa da bu motivasyonlarla ilintili olarak sırların türleri de olabilir (Dongjin, Jiang ve Gorn, 2018). Örneğin uyuşturucu madde kullanımı gibi yasadışı sırlar karanlık sırlarken sürpriz parti hazırlığı gibi sırlar olumlu sırlar olabilir. Nitelik olarak farklılaşsa da temelinde bir bilgiyi başkasından gizlemek güdüsü yer almaktadır. Lane ve Wegner (1995)'e göre birisinin kendisi yalnız iken yapabilecekleri mahremiyetle ilişkili iken; gizlilik, sosyal etkileşimle ilişkili olarak kavramlaştırılmaktadır (Slepian, Camp ve Masicampo, 2015). Yalnızlık gizliliği sağlamak açısından iyi bir koruyucudur. Mahremiyet, bir bireyin özel alanını ifade ederken gizlilikte bir şeyleri bilinçli olarak gizleme çabası vardır. Gizlilik bağlamında ele alındığında bilgiyi ötekilerden saklama arzusu, bir kişiye karşı da olabilecekken bir sosyal gruba karşı da olabilir. Dolayısıyla gizlilik doğası gereği en az iki kişiyi kapsamalıdır. Bazı araştırmacılar (örn. Thomas, Johnson ve Jewell, 2016; Slepian vd., 2017) gizlilik eyleminin iki kişinin etkileşiminde bir bilginin saklı tutulması ve paylaşıımaması, iletişim ortamına farklı veya yanlış bir bilgi eklenmesi ya da iki şekilde de gerçekleştirilebildiğini öne sürerken, diğer bazı araştırmacılar (örn. Lane ve Wegner, 1995), gizlilik güdüsünün altında başkalarını kandırma veya aldatma gibi yanlış bilgi aktarımı olmadığını, sadece mevcut bilgilerin bilinmesini engellemek amacıyla yalan söylemenin gizliliğe dahil olabilecekken yanlış olduğu bilinen bilgileri yani yalanları aktarmanın aldatma olduğunu öne sürmektedir. Özetle iletişim ortamından çıkarılan bilginin varlığı gizlilikle tartışmasız ilişkilendirilirken, gizliliği yaratmak amacıyla ortama eklenen bilginin yanlış olması aldatma ile ilişkili ele alınmaktadır.

Başkalarının doğru bilgileri bilmesini kasıtlı olarak önleme kararı (Critcher ve Ferguson, 2014), sırrı bir yük olarak "taşıyan" kişi üzerinde gerek fiziksel gerekse psikolojik sağlık, diğer bir ifadeyle iyi oluş üzerinde olumsuz etkileri oluşturabilir (Lane ve Wegner 1995; Slepian, Masicampo, Toosi ve Ambady, 2012). Öte yandan, gizlilik suçluluk duygusunu da ortaya çıkarabilmektedir. Suçluluk duygusu ile yük taşıma arasında bağlantı kuran Vangelisti (1994) suçluluk duygusunun yük taşıma hissini artırdığını savunmuştur.

Çok yaygın bir olgu olarak gizlilik (Kelly, 2002) en çok psikolojik alanında araştırılıyor olsa da tüketimde gizliliğe yönelik ilgi pazarlama alanında da artmaya başlamıştır.

\section{Sosyal Kimlik ve Gizli Tüketim}

Gizli tüketim bir ürünü veya hizmeti başkalarından gizleyerek tüketme eğilimi şeklinde tanımlanmaktadır (Rodas ve John, 2020). Gizli tüketim çeşitli şekillerde gerçekleşebilmektedir. Tüketiciler özel alanlarında olduğu kadar kamusal alanlarda da gizli tüketim yapabilirler. Örneğin bir tüketici kahve termosunun içerisine alkol koyarak da bu tüketimini işyerinde vs. gerçekleştirebilir. Öte yandan gizli tüketim mutlaka ürün temelinde değil, marka temelinde de olabilir. Sosyal grubun markaya karşı önyargısı da tüketimi gizleme arzusunu tetikleyebileceği gibi çevresi tarafından sağlıklı beslendiği düşünülen bir tüketicinin de sağlıksız atıştırmalık ürünleri tüketimini gizleme arzusu olabilir (Fournier, 1988).

Thomas ve Jewel (2019), bir tüketicinin marka ve ürün tüketiminin başkaları tarafından bilinmesini istememesinin altında yatan motivasyonlarını şu şekilde sıralamaktadırlar: Marka kullanımından kaynaklanan utançtan kaçınmak, diğerlerince yargılanmak istememek, diğer markalara sadık olan arkadaşlarıyla çatışmadan kaçınmak, diğerlerine uyum sağlamak, diğerlerini üzmekten ya da utandırmaktan çekinmek, iyi görünmek, farklı olmayı istemek, marka kullanımını bireysel ya da mahrem alanda tutmayı istemek.

Diğerlerinin birey hakkındaki bilgilere erişiminin kısıtlı olması anlamındaki mahremiyet sosyal çevredekilerin kişi hakkında bilgisi olmaması, sosyal ilginin bu kişiye yönelmemesi ya da kişiye fiziksel ulaşımlarının olmaması ile sağlanabilmektedir (Gavison, 1980; Masur, 2019).

Diğerlerinden aktif olarak bilgi gizleme, sosyal ilgiden kaçınarak mahremiyeti korurken gruba uyum sağlama çabası ile ilişkilendirilmektedir: sosyal uyumsuzluktan kaçınmak için yapılan gizli tüketim, tüketicinin genellikle normlar veya sert standartlarla çevrilmiş bir tüketim bağlamında, tüketimi dolayısıyla sosyal olarak uyumsuzluğu nedeniyle artan sosyal ilgi sonucunda dışlanma riskinden kaçınma amaçlıdır (Ashton, Lee ve Paunonen 2002; Dongjin vd., 2018). Sosyal etkileşimle birlikte sırrın ifşa edilme riski oluşabilmektedir (Ashton vd., 2002). Tüketici, gizli olarak tüketim pratiği ile istemediği sosyal ilgiden ve dolayısıyla da sırrının ortaya çıkması riskinden kaçınma çabasındadır (Dongjin vd., 2018). 
Sosyal kimlik teorisine (Tajfel, 1974; Tajfel ve Turner, 1979) göre bireylerin benlik ve kimlikleri içinde bulundukları sosyal grupların değerleri, tercihleri, eğilimleri ve yönlendirmelerinden etkilenmektedir. Bu etki, bir yandan benlik algısı ve kimlik tanımlarında, sosyal sınıflama ve grup içi ve gruplar arası ilişkilerde, diğer yandan da tüm sosyal ve psikolojik süreçlerdeki, tüketim pratiklerini de kapsayan, davranışsal çıktılarda gözlemlenebilmektedir. Tüketicinin sosyal kimliği, örneğin, ürün ve marka tercihlerini, imaj ve fiyat algılarını, satın alma istek ve niyetlerini ve kişinin kendini marka ile özdeşleştirmesini etkilemektedir (Thomas vd., 2016). Tüketici içinde bulunduğu sosyal gruptan dışlanmamak, diğer bir ifadeyle uyum sağlamak ve grup-içi olmak için, grubun tüketimine karşı olumsuz tutum taşıdığı ürün veya hizmetlerin gizli bir şekilde tüketimi tercih edebilir. Tüketiciler, sosyal yaptırımlarının şiddetli olup algıladığı tüketicinin yakalanma riskinin düşük olduğu durumlarda tüketim davranışlarını gizlemektedirler (Thomas, Jewell ve Johnson, 2015).

Sosyal kimlik teorisinde, her ne kadar bireyin grup değerlerini içselleştireceği öne sürülse de (Tajfel ve Turner, 1979), tüketim pratiklerinde grup değerleri ile özdeşlik olmadığı fakat gruba uyma isteğinin sürdüğü durumlarda tüketici, mahremiyetini ve sosyal kimliğini sürdürebilmek için gizliliğe ihtiyaç duyabilmektedir. Örneğin bireyin marka tercihinin ya da marka kullanma pratiğinin sosyal grubunun değerleri ve marka tercihi ile çatışması durumunda tüketici ya kimliği ile tutarlı kalacak ve farklıı̆̆ın ortaya koyacak şekilde kendi tüketimini sürdürebilir ya da gizli tüketime yönelerek grup tarafından onaylanmayan markayı farklı sosyal bağlamlarda kullanmaya devam edebilir.

Yakın ilişkilerde sır tutmak samimiyetin zedelenmesi gibi olumsuz sonuçlara yol açabileceği gibi (Critcher ve Ferguson, 2014) tüketim eylemlerini bazen gizli tutmak kavgadan kaçınmaya ve duyguların incinmemesine yardımcı olabilmektedir (Gullo, Brick ve Fitzimons, 2018). Yakın partnerlerden tüketimi gizlemenin iki nedeni vardır; kaçınma ve teşvik. Kaçınma, Dongjin vd. (2018)'nin belirttiği gibi partnerin yargılamasından veya partnerin uzaklaşmasına neden olacak eylemden kaçınmayı temsil ederken; teşvik etme motivasyonu ile gizli tüketim ise partnerin herhangi bir sebeple tüketmediği tüketim nesnesine yönelik partnere destek amacını gösterir. Örneğin partnerlerden biri diyet yaparken diğer partner sadece teşvik maksatlı onunla aynı yemeği yiyebilir, onun tüketmediği gıdaları gizli tüketme eğiliminde olabilir. Gullo vd. (2018)'nin çalışmalarında kaçınma motivasyonuna dayalı gizli tüketimin kişiler arası yakın ilişkilere etkisinin nötr ya da pozitif olacağını öne sürmektedirler. Yazarlara göre bir şeyleri gizlemekten kaynaklanan suçluluk duygusu tüketicinin kendisi üzerinde olumsuz etki etse de suçluluk duygusu kişiyi ilişkiye daha fazla önem vermeye itebilmektedir. Elbette, bu bulgunun tersi sonuçlarla da karşılaşmak, örneğin takıntılı-zorlantılı tüketim (obsessive-compulsive consumption), yeme bozuklukları, kumar ve uyuşturucu kullanımı gibi zararlı sonuçları olan tüketim eylemlerinde sır tutma sonucunda hem sır tutan tüketicinin hem de yakın ilişkilerinin zarar görebileceğini öne sürmek de mümkündür (Rodas ve John, 2020).

Gizli tüketim motivasyonun altında toplumsal tabular ve gelenekler de yer alabilmektedir. Toplumun "erdemsiz" kabul ettiği ürünlere bakış açısı, bu ürünlerin tüketiminde utanç ve suçluluk gibi duygulara yol açabilecekken sosyal kabul görme arzusu bireyleri bu ürünlerin tüketimini gizleme eğilime yöneltebilir. Wundt (2003)'a göre tabu insanlığın yazıya dökülmemiş kadim kanunlarıdır. Tabu kelimesinin çevirisi her ne kadar güçse de iki zıt anlama sahiptir. Bunlardan ilki kutsal, kutsanmış anlamlarına gelirken diğeriyse tekinsiz, tehlikeli, yasak, kirli manalarına gelmektedir (Freud, 2021). Tabunun iki anlamının birbirlerini besledikleri de düşünülebilir; kutsal olan ve kutsal olmadığı için kirli olanlar. Tabular kendilerinden menkul yasalar olup genel olarak gerekçesi yoktur, kökenleri bilinmez ve kutsala hizmet eder. Erdemli görülmeyen ürünlere bakış açısı tüketimi tabulaştırarak gizli tüketime yol açabilir. Örneğin İslam inancında tüketimi yasak olan domuz eti, müminlerce erdemsiz kabul edilmekte ve kutsala dayanarak tabulaştırılmaktadır. Benzer şekilde alkollü ürünlerin tüketimi de kimi zaman sosyal ve dini nedenlerle olumsuz karşılanmaktadır. Dolayısıyla tüketimi tabulaştırılan ürünlerin tüketicilerce gizli tüketmesi söz konusu olabilmektedir. Diğer yandan günlük hayatta en yaygın hissedilen duygularından biri olarak utanç duygusu Tangeny (1999)'e göre bir bireyin davranışı sosyal kabul görmediği durumlarda da ortaya çıkar. Utanç duygusu tüketici davranışlarında da önemli bir yere sahip olup tüketiciler beklenen veya hissedilen utanç verici tüketimle de baş etmek zorundadırlar (Krishna vd., 2019). Utanç duygusunun yönlendirdiği gizli tüketim, kişisel faydası yüksek algılansa da sosyal açıdan utanca yol açabileceği düşünülen erdemsiz ya da mahrem ürünlerin (örn. alkol, kondom, saç ekimi ya da botoks uygulaması) ya da daha da ilerisi, toplumda stigmatize edilmiş çağrışımlara sahip ürün veya tüketim 
pratiklerine (örn. büyük beden veya gök kuşağı renklerinde kıyafet) hitap eden ürün ve markaların çağrışımlarından kaynaklanan utançtan kaçınmak için gerçekleştirilebilir. Utanç verici tüketimle baş etmek için tüketiciler kendi stratejilerini geliştirebilirler. Çevrimiçi alışveriş tercihi, başka muhitlerden alışverişi tercih etme gibi seçenekler bu duruma örnek olarak gösterilebilir. Bunun bir başka yöntemi de tüketicilerin alışveriş sepetlerine başka ürünler ekleyerek utanç verici ürünü gizlemeye çalışmak olabilir (Blair ve Rose, 2013). Örneğin; kadın peti satın almak isteyen tüketici alışveriş sepetine ilişkisiz başka ürünler ekleyerek utanç duyduğu satın alma eylemini gizlemeye, diğer bir ifadeyle görünürlüğünü azaltarak maskelemeye (Nicholas vd., 2015) çalışabilmektedir.

Tüketimde gizlilik, kişinin gizli tuttuğu bilgiyi tekrar tekrar düşünmesine ve hatta bastırmaya çalıştıkça daha da fazla düşünmesine yani zihinsel meşguliyetinin giderek artmasına neden olmaktadır. Uzun dönemde takıntı düzeyine kadar artabilen zihinsel meşguliyet nedeniyle tüketicilerin markayla daha derin ilişkiler kurmasını sağlayarak marka-benlik bağlantısını ve dolayısıyla marka sadakatini güçlendirdiği de bulunmuştur (Lane ve Wegner, 1995; Rodas ve John, 2020). Ancak tüketicinin dikkatinin gizli tüketimden başka konulara dağılması gibi durumlarında zihinsel meşguliyetin takıntı düzeyine yükselmesi söz konusu olmayacağından söz konusu sonuçlar ortaya çıkmayabilmektedir. Ayrıca, zihnin meşgul olduğu ürün sevilen bir ürünse tutumların pozitif yönde daha da güçlendiği, sevilmeyen bir ürünse negatif yönde daha güçlendiği bulguları ürüne karşı olan ilk tutumların niteliğinin de gizli tüketimin çıktılarını etkilediğine işaret etmektedir (Rodas ve John, 2020). Diğer ifadeyle tüketicinin gizli tüketime zihinsel olarak odaklanmasının benlik-marka bağlantısını ve marka sadakatinin artması sonucu tüketicinin dikkatinin dağılmadığı ve üründen hoşlandığı durumlarda ortaya çıkmaktadır.

Tüketim sürecinde bilgileri gizlemeye çalışmak ve ifşa olmayı önlemek için çaba sarf etmek, genel anlamda tüketicinin fiziksel ve psikolojik iyi oluşunu olumsuz etkileyebilmektedir (Lane ve Wegner, 1995; Critcher ve Ferguson, 2014). Bununla birlikte, gizli tüketimden olumlu sosyal tepkiler beklendiği ve tüketimin keyifli algılandığı durumlarda sır saklamanın zihinsel olarak yıpratıcı etkisine rağmen tüketimden alınan zevkin bu etkiyi bastırması söz konusu olabilmektedir (Yang, Deng ve Jia, 2018). Tersi durumunda olumsuz sosyal tepkiler alması beklenen tüketim eylemini gizlemenin tüketiciye sadece bir yük oluşturmadığını aynı zamanda tüketicilerin sırlarının ifşa olacağı endişesiyle dehşete kapılarak tüketim keyfinin azalmasına yol açacağı öne sürülebilir.

\section{Gizli Alkol Tüketimine İlişkin Nitel Araştırma}

\subsection{Araştırma Metodolojisi}

Bu çalışma Türkiye'de özellikle muhafazakâr kesimlerce neredeyse tabu seviyesinde hoş karşılanmayan alkollü içki tüketimine yönelik gizli tüketim eğilimini araştırmaktadır. Araştırma soruları sosyal çevrenin ve alkollü içki tüketimini yönlendiren diğer faktörlerin neler olduğu, gizli tüketimi yönlendiren tüketici motivasyonlarının neler olduğu ve gizlilik ihtiyacı ya da arayışının tüketici pratiklerine yansımasının nasıl gerçekleştiğine yöneliktir. Gizli alkollü içki tüketimi bir olgu olarak tanımlanmıştır. Araştırma, fenomenolojik araştırma olup odak nokta katılımcıların bir olguyu nasıl deneyimlediklerini analiz etmektir. Fenomenolojik araştırmada, araştırmacı olguyu deneyimleyen kişilerden veri toplamakta ve bireylerin deneyimlerinin özüne ilişkin kompozit betimlemeler geliştirmektedir (Creswell ve Poth, 2018). Betimlemeler katılımcıların neyi nasıl deneyimlediklerini kapsamaktadır.

Keşif amaçlı olarak yapılan çalışmada nitel araştırma yöntemlerinden derinlemesine görüşme tekniği kullanılmıştır. Araştırmanın ana kütlesini 18 yaşüstü, eğitim seviyesi yüksek, alkollü içki tüketen ve tüketim sürecinde gizlilik ihtiyacı duyan tüketiciler oluşturmaktadır. Covid pandemisi nedeniyle yüz yüze görüşmelerin kolay yürütülebileceği şekilde araştırmacıların ikamet ettiği İzmir şehrinde alkol tüketimini seven kişiler arasından araştırma problemi hakkında en iyi şekilde bilgi alınacağı düşünülenler amaçlı örnekleme tekniği (Creswell ve Poth, 2018) ile örneklem oluşturulmuştur. Öz-etiketleme, özünde kişinin kendisi hakkında bir inanç edinme sürecini ifade ettiğinden (Rotenberg, 1974) kendisini gizli alkol tüketicisi olarak tanımlayan kişiler, gizli alkol tüketicisi kabul edilmiş ve örneklem bu kişilerden oluşturulmuştur. Katılımcılar çalışmaya davet edilirken alkol tüketimi ve gizlilik üzerinde konuşulacağı söylenmiş ancak katılımcıları şartlandırmamak 
ve olası reaktivite sorunundan kaçınmak için detaylı bilgi verilmemiştir. Açık uçlu sorulardan oluşan yapılandırılmamış görüşmeler, katılımcıların kendilerini rahat hissedecekleri belirttikleri ortamlarda yüz yüze gerçekleştirilmiştir. Aralık 2020 ile Ocak 2021 arasında yapılandırılmamış görüşme tekniği ile gerçekleştirilen görüşmeler onay alınarak kaydedilmiş ve sonrasında deşifre edilerek nitel veri analizine hazır hale getirilmiştir. En az bir saat süren görüşmeler sonucunda ortaya çıkan temaların 10 görüşme sonrasında doyuma ulaştığının gözlemlenmesi ile veri toplama süreci sonlandırımıştır. Veri analizleri, temaların doyuma ulaşıp ulaşmayacağını belirleme açısından görüşmeler devam ederken başlamış ve sonlandırılan görüşmeler sonrasında da devam etmiştir.

Katılımcıların demografik profili Tablo 1'de gösterilmiştir. Anonimliği korumak için katılımcıların açık isimleri kullanılmamıştır. Katılımcılar, 24-36 yaşları aralığında ve en az ön lisans eğitim seviyesindedir. Katılımcılar alkol tüketim seviyelerini sosyal içici şeklinde tanımlamaktadırlar. Katılımcıların demografik profilinin çok fazla çeşitlilik içermemesi çalışmanın bulgularının genel topluma teori-temelli ve analitik genellemesi (Daymon ve Holloway, 2002; Jensen, 2002) açısından kısıt oluşturmaktadır. Bu kısıta rağmen, nitel veri miktarı arttıkça analiz verimliliğinin düşmesi sorunu nedeniyle homojen grup özelliği gösteren katılımcılardan elde edilen temaların doygunluğa ulaşması ile veri toplanması durdurulmuştur. Heterojen örneklemlerde gizli alkol tüketimi olgusunun araştırılması ileriki çalışmalara bırakılmıştır.

Tablo 1. Katılımcıların Demografik Profilleri

\begin{tabular}{|c|c|c|c|c|c|c|c|}
\hline Katılımcı & Yaş & Cinsiyet & Eğitim & Meslek & $\begin{array}{c}\text { Bireysel } \\
\text { Aylık Gelir }\end{array}$ & $\begin{array}{c}\text { Aile Sosyo- } \\
\text { Ekonomik } \\
\text { Sınıfı }\end{array}$ & $\begin{array}{c}\text { Medeni } \\
\text { Durum }\end{array}$ \\
\hline M.Ö. & 29 & Erkek & Lisansüstü & Yönetici & $8000 \mathrm{TL}$ & $\mathrm{C} 2$ & Evli \\
\hline M.K. & 26 & Erkek & Lisansüstü & Mühendis & $5000 \mathrm{TL}$ & $\mathrm{C1}$ & Bekar \\
\hline A.K. & 26 & Kadın & Lisansüstü & Ekonomist & $4300 \mathrm{TL}$ & $\mathrm{E}$ & Bekar \\
\hline S.D. & 28 & Kadın & Lisans & Bilgi İşlemci & $3500 \mathrm{TL}$ & B & Bekar \\
\hline Y.D. & 29 & Erkek & Lisansüstü & Antrenör & $6000 \mathrm{TL}$ & $\mathrm{C} 2$ & Bekar \\
\hline T.D. & 34 & Erkek & Lisans & Öğretmen & $6500 \mathrm{TL}$ & $\mathrm{C2}$ & Evli \\
\hline A.P. & 36 & Kadın & Önlisans & Tıbbi Sekreter & $3000 \mathrm{TL}$ & B & Evli \\
\hline M.D. & 27 & Kadın & Lisansüstü & Yönetici Asistanı & $6000 \mathrm{TL}$ & B & Evli \\
\hline A.F. & 24 & Erkek & Lisansüstü & Mühendis & $4500 \mathrm{TL}$ & $\mathrm{C1}$ & Bekar \\
\hline H.Ö. & 30 & Erkek & Lisans & Yönetici & $12000 \mathrm{TL}$ & B & Bekar \\
\hline
\end{tabular}

\subsection{Gizli Alkol Tüketme Motivasyonları: Ne Şiş Yansın Ne Kebap}

Alkollü içki tüketiminde gizliliğin nedenlerinden biri Türk toplumunda erdemsiz ürünlere bakış açısı ve bu ürünlerin tüketimlerini özellikle kutsala dayandırarak stigmatize edilmesi ve bazen de tabulaştırılmasıdır. Her ne kadar tütün mamulleri tüketimine yönelik stigmatize etme ya da tabulaştırma söz konusu değilse de özellikle de dini vecibelere bağı kesimlerce alkollü ürün erdemsiz kabul edilmekte, tüketimine kötü bakılmakta ve hatta tabu haline getirilmektedir. Öyle ki geleneksel Türk adetlerinden olan kı isteme törenlerinde damat adayı için sorulan yahut belirtilen ilk konulardan birisi alkol tüketimine yöneliktir. Bundan dolayı da bazı tüketiciler alkol tüketimlerini gizlemek istemektedirler.

Araştırmanın bulguları alkollü içki tüketiminin tabulaştırılmasının İzmir gibi daha açık ve toleranslı görülen bir ortamda dahi söz konusu olduğunu göstermektedir. Aşağıdaki alıntılar olumsuz tutumun boyutlarının stigmatizasyon seviyesine kadar çıkabildiğine işaret etmektedir. Stigma, istenmeyen ve kötü bakılan bir özellik ya da leke olup stigmatizasyon kişinin bu nedenle toplumdaki diğer kişilerin gözündeki statüsünü düşürecek şekilde damgalanmasıdır (Goffman, 1963; Heijnders ve Van Der Meij, 2006). Erdemsiz bir ürün ve hatta "canilikten daha kötü" görülen alkollü içkilerin tüketimi, kullananların "kötü yola düşmesi" olarak değerlendirilebilmekte, kullananın çevresini sadece üzmekle kalmayıp sosyal grup ya da toplumsal beklentilere ters düştüğü için kullanan kişi hakkında hayal kırıklıkları yaratabilmektedir. Çalışma bulguları, alkol kullanımı bilgisinin sosyal ortamdan çıkarılması aktif olarak çıkarılarak gizliliğin sağlanması eylemini 
yönlendiren motivasyonlar, bazen sadece basit bir şekilde diğerlerine uyum sağlamak, istemediği sosyal ilgiden kaçınmak, kendi sosyal pozisyonunu ve iyi oluşunu korumak şeklinde gerçekleşmektedir. Bu seviyede daha çok sosyal uyumsuzluktan kaçınmak amaçları öne çıkmaktadır. Sosyal etkileşim boyutunda dikkate alındığında ise katılımcılar alkol tüketimi bilgisini saklı tutarak diğerlerini hayal kırıklı̆ına uğratmaktan ve üzmekten kaçınmakta ve çevresine iyi görünmeye çalışmaktadır.

Tüketim normların sertleştiği sosyal ortamda ise stigmatizasyondan, diğer bir ifadeyle diğerlerince yargılanmak ve dışlanmak istememenin gizliliği "ihtiyaç" seviyesine çıkardığı görülmektedir. Bu düzeyde, alkol tüketimi sadece olumsuz değil, "kötü yola düşürecek" düzeyde erdemsiz davranış olduğundan yakın ilişkide olunan kişileri sosyal çevrelerine karşı utandırmamak için "gizlemek zorunda" olunan bir davranış haline gelmektedir.

"Toplum olarak çok fazla tabusu olan bir toplumuz ... işte sigara gibi, alkol gibi... bir sevgilinle el ele dolaşmak, alkol içmek, alkol kullanmak... bizim toplumumuzda birçok canilikten daha kötü bir davranış olarak görülüyor... gizlilik ihtiyaç haline geliyor." (M.Ö., 29).

"Mesela benim babam da hani nasıl söyleyeyim muhafazakâr bir ailede büyüdüğü için onların gelenek ve göreneklerinden bir şeyler aldığı için bu konuda sığınma mı denir ya da herhangi bir şey mi denir izin vermez, katıdır. O yüzden hani aile yapısından dolayı gerek bulunduğumuz yer gerek yetiştirildiğimiz çevreden dolayı saklama ihtiyacı duyuyorum." (A.K., 26).

"Alkol tüketimimi ailemden gizliyorum. Çünkü ailem alkol tüketiminin yanlış bir şey olduğunu düşünüyor ve alkol tüketen kişilere karşı pek olumlu açıdan bakmıyorlar ve üzülürler benim alkol kullandığımı görürlerse ve bilirlerse... Çünkü benden beklentileri çok fazla. Bu yüzden alkol tükettiğimi görürse kendi kendine çocuğum kötü yollara düştü diye düşünebilir. Bu yüzden alkol tüketimimi ailemden gizlemek zorundayım. Sırfonların hayal kırıklığı olmamak için ve onları üzmemek için." (A.F., 24).

Illeri kapitalist dönemde kamu yönetimlerinin erdemsiz ürünlerin tüketimini azaltmaya veya yasaklamaya ilişkin geliştirdiği ekonomi ve sağlık politikaları ülkeler arasında da çok benzerlikler içermektedir (Ver Eecke, 1998; Mann, 2006). Ancak kamunun değerlendirmesinden bağımsız olarak, sosyal çevrenin erdemli ve erdemsiz olup olmadığına ilişkin değerlendirmeleri farklı olabilmektedir. Söz gelimi, kamu yönetiminin tüketimini azaltmaya çalıştı̆̆ı ve bireysel ve toplumsal düzeylerde olumsuz etkileri açık olan tütün mamullerine karşı Türk toplumunda yaygın olarak erdemsiz ürün değerlendirmesi yapılmamaktadır. Ayrıca ürünlerin erdemsiz olup olmadığına ilişkin toplumsal değerlendirmeler kültürler arasında da farklıık gösterebilmektedir. Avustralya'da yapılan nitel bir çalışmada alkol tüketiminin sosyal yaşamın ve toplumla bağlantı kurmanın doğal bir parçası olduğu ve hatta alkol tüketmemenin yabancılaşma ve stigmatizasyona kadar gidebildiğini ortaya konmaktadır (Pettigrew, 2001). Alkol tüketimi İslam inancına göre haram olsa da Türk toplumunda tüketimi devam etmekte ve hatta rakı gibi "milli" alkollü içeceklerin tüketimi geçmişten beri sosyal hayatta yer almaktadır. Bununla birlikte, bir yandan 1980 sonrası batı tüketim kültürünün de Türk tüketicisinin tüketim pratiklerine ve değerlerine yansıması (örn. Sandıkçı ve Ger, 2002), diğer yandan da Kandiyoti $(2002,2016)$ 'nin de işaret ettiği gibi 1980 sonrası toplumsal kimliklerdeki değişim eğilimleri ile birlikte özellikle 2002 sonrası muhafazakar aile değerlerinin kamu politikası olarak tatbik edilmesi, özellikle alkollü içkilerin tüketimine karşı tüketici tutumlarında ve tüketim pratiklerinde eskiye göre daha sert çelişkiler yaratmıştır.

Geleneksel toplumlarda sosyal değerler ve normların bireylerin yaşantısında ağırlığı yüksek olmakta ve insanların davranışlarının birçoğu diğerlerinin beklentilerini karşılamak için yapılmaktadır. Bu durum bireylerde kimlik bunalımına yol açarak özgürce seçim yapamayan kişilerde onaylanacağı önceden belirlenmiş kurallara uygun davranış biçimini sergilemek şeklinde gözükür (Geçtan, 2020). Araştırma bulguları, alkol tüketiminin her ne kadar Türk toplumunda tabu olduğu ifade edilse de İzmir bağlamında sosyal çevre açısından geniş toplumdan çok aileden ve yakın çevreden gizlendiğini göstermektedir. Yaraman (2018)'ın, Osmanlı liman kentinin çoğulcu modernliğiyle Cumhuriyet modernliğinin milli ve Atatürkçü özelliklerinin "uzlaşmaz" kolajı olarak nitelediği İzmir bağlamında toplumsal muhafazakarlığın Türkiye geneline kıyasla daha düşük olduğunu öne sürmek mümkündür. Diğer yandan, kitlesel göç alan bir şehir olan İzmir'de, İstanbul ve 
Ankara gibi diğer büyükşehirlerde olduğu gibi, bir yandan Batılılaşma ve modernleşme diğer yandan da aile içi kırsal ve muhafazakâr değerlerin korunması ve yüksek sosyal kontrol de söz konusudur (örn. Erman, 1998).

Ailelerin alkol tüketimine olan olumsuz bakış açısı nedeniyle alkol tüketmek isteyen bireyler arasında bir tercih çatışması (Olsen ve Grunet, 2010) meydana gelmektedir. Aşağıda sunulan alıntılarda alkollü içki tüketiminden keyif alan katılımcıların toplum genelinden çok yakın çevreleri ve aile değerleri ve normlarına karşı olduğu için tüketimlerini gizledikleri, "konusunu bile açmadıkları" görülmektedir. Katılımcıların bireysel değerleri ile sosyal değerlerinin çatıştığı durumda ne bireysel ne de sosyal değerleri değiştirme girişimi söz konusu olmamaktadır. Yakın çevredekilerin "anlamayacakları" tüketim tercihleri için kimseyi "yormaya gerek" görülmemektedir. Deneyimlenen çatışmalarla baş etmede gizliliğin bir çözüm olarak kullanılmasının gerekçesi 27 yaşındaki M.D.'ye göre "ne şiş yansın ne kebap"tır.

Tercih çatışması olması durumunda sosyal gruplarına daha çok önem veren bireyler grubun isteklerine daha çok uyarlarken sosyal grubun isteklerini gözetmeyen bireyler ise kendi istekleri doğrultusunda hareket etmektedirler. Ancak tercih çatışması durumunda bireylerin öz istekleri de ağır basabilmektedir. Öz isteklerin ağır basması ve grup beklentilerinin farklı olması nedeniyle bu bireyler gizli tüketim eylemini tercih etmektedirler (Thomas vd., 2016). Bu sayede de grubun istekleriyle uyumlu davranıyormuş gibi gözükerek kişisel arzularına da bağıı kalmaktadırlar.

"Annem de babam da alkol tüketmiyorlar. Dini vecibelerini de yerine getirmeye çalışırlar. Bu yüzden benim de tüketmemi istemiyorlar. Ben de onlara duyduğum saygıdan dolayı ve çekindiğim için onların yanında alkolün lafını bile açmıyorum. Hiçbir zaman alkol muhabbeti alkol konusu içmeyi bırak konusunu bile açmıyorum ve eğer tüketeceksem de mesela gizli bir şekilde. Çünkü çekiniyorum ve saygı duyuyorum o yüzden gizleyerek yapıyorum yani bunu. Ha bir yandan da alkol bana keyif verdiği için ve alkol tüketmeyi sevdiğim için bunu da yapmak istiyorum. Bundan geri kalmak istemiyorum hani. Tamamıyla kendimi kapatmıyorum ama ne şiş yansın ne kebap şeklinde ailemi de kırmamak için onları çok sevdiğim ve saygı duyduğum için onlardan bu eğilimimi gizliyorum." (M.D., 27).

"Ailem bunu (alkol tüketimini) çok fazla onaylamaz. Çevremden de insanlar biraz daha kapalı, muhafazakâr insanlar der ki hani tüketmesen daha iyi olur senin için veya daha sert yaklaşımlarda da bulunan insanlar var. Onun için şey derim yani hani tamam, onları kırmamak için... O insanların belli başlı değerleri var. Benim de o değerlerim var ama benimki bir tık daha benim için esnetilebilir olmuştur, o insanlara saygı duyduğum için bunu kesinlikle bilip üzülmelerini veya benimle bu konuda tartışmalarını hani, tercihe bağı bir sebepten tartışmak çok saçmadır." (M.K., 26).

"Alkol tüketiminde aileden gizleme ihtiyacı hissediyorum aslında şu şekilde onlar için yıkılmaz bir tabu gibi bir şey. Yani onlar çünkü o dinamiklerle büyüdü, o dinamiklerden geldi onlar şunu düşünüyor, alkolü kötü insanlar kullanır, kesin işte sarhoş olursun, etrafına zarar verirsin, hiçbir şekilde alkole başlama bir daha ondan kurtulamazsın, ailen yuvan bozulur, şöyle olur, böyle olur. Hem onlara duyduğum saygı açısından hem de onlara bunları açıklayamayacağımı düşündüğüm için bu çabaya girmemem gerektiğini düşünüyorum çünkü anlamayacaklar. Onun için ne beni ne de onları yormaya gerek yok ... ailede daha işin içinde bir saygı, hayal kırıklığına uğratmama gibi dinamikler işin içine giriyor. Şimdi buradaki motivasyonum onları mutsuz etmemek." (Y.D., 29).

Psikolojik düzeyde ise alkol tüketenlerin tüketimden dolayı utanç ve suçluluk duygusu hissettikleri gözlenmiştir. Katılımcılar alkol tüketimlerinden dolayı ailelerinin üzüleceğini ve toplumun bakış açısından dolayı ailelerine ve/veya kendilerine söz geleceğini düşünmektedirler. Bu yüzden bu tüketimlerinden bir suçluluk duyarlarken bu tüketimleri ortaya çıktığında onların hayal kırıklığına uğrayacakları düşünülerek bundan da bir utanç duymaktadırlar. Tüketicilerin utanç verici durumla baş etmeleri gerekliliği (Krishna vd., 2019) düşünülünce alkol tüketimi tüketici davranışlarına gizli tüketim olarak yansımaktadır. 


\section{3. "Olması Gereken” Benliğin Ağırlığı Karşısında Mahremiyeti Sürdürme: Minimum Risk}

Higgins (1987)'in benlik uyuşmazlığı (self-discrepancy) teorisine göre insanlar kendilerini değerlendirirken gerçek benlikleri ile iki diğer benliği, ideal benliği ya da normatif "olması gereken" (ought) benliği karşılaştıırılar. Karşılaştırmada kendileri ya da ötekilerinin (spesifik referans grupları ya da genel olarak toplum) bakış açısını temel alınabilir. Kişinin gerçek benliği ile ideal benliği arasındaki uyuşmazlık, kendisinin ya da önem verdiği kişilerin ideallerine ulaşamadığı için kişide üzüntü, hayal kırıklığı ya da tatminsizlik yaratmaktadır. Gerçek benlik ile normatif benlik arasındaki uyumsuzluk görevlerini ve sorumluluklarını yerine getirmediği ve aynı zamanda diğerleri tarafından yargılanabileceği için kişide ise kaygı, korku, tedirginlik gibi ajitasyon temelli duygulara neden olmaktadır (Higgins, 1989).

Goodwin (1992)'e göre tüketiciler tüketim deneyimlerinin kalitesini artırmak, onaylamayan referans gruplarının müdahil olmalarından kaçınmak ve benlik uyuşmazlığının yarattığı bilişsel rahatsızlığı çözmek için tüketimlerini gizli tutmaktadırlar. Tüketimde gizliliğin tamamen normalden sapan bir davranış olmadığını da ifade eden Goodwin (1992), bir referans grubundan saklanan tüketim bilgisinin diğer bir gruba karşı açık olabildiğine de işaret etmektedir.

Tüketicinin mahremiyeti ya kendisini ifşa etme ya da başkalarının mahrem alanına girmesi durumunda ortadan kalkmaktadır (Masur, 2019: 47). Tüketicinin kendini ifşa etmeyi (self-disclosure) kontrol altına almaya çalışması, tüketimden alınan zevki sürdürme, kendi hakkındaki bilgileri diğerlerinden koruma ve benlik-imajını koruma amaçlarıyla gerçekleştirilebilmektedir (Goodwin, 1992). Tüketici, bilgiyi mahrem alanında kendisi ile ilgili nedenlerle gizli tutarken bilginin çıkması durumunda oluşabilecek suçluluk duygusundan korunmayı hedeflemektedir. Mevcut çalışma, tüketicinin kendini if̧̧a etmeyi kontrol ederek tüketim bilgilerini mahrem alanda saklı tutma olgusundan çok sosyal çevredeki ötekilerin tüketicinin mahrem alanına girmesi durumunda bilgi gizleme olgusuna odaklanmaktadır.

Tüketici, ötekilerin mahrem alana girmesi üzerinde kontrole, Goodwin (1992)'e göre (a) diğerlerinin davranışsal tepkilerinden kaçınma, (b) utanç verici durumdan kaçınma ve (c) diğerlerinin söze dökmediği değerlendirmelerden kaçınma durumlarında ihtiyaç duymaktadır. Diğerlerinin davranışsal tepkilerinden kaçınma ve utanç verici durumdan kaçınma amacında benlik uyuşmazlığı gerçek benlik ile normatif (ought) benlik arasındadır. Tüketici küçük düşme, utanma, eleştirilme gibi sonuçlardan kaçınmaya çalışır. Diğerlerinin söze dökmediği değerlendirmelerden kaçınma amacında ise uyuşmazlık, gerçek benlik ile ideal benlik arasındadır ve tüketici diğerlerini hayal kırıklığına uğratmaktan kaçınmaya çalışır.

Çalışmanın bulguları, katılımcıların gizli alkol tüketiminin kendini ifşa etmesinden (self-disclosure) kaçınmaktan çok ötekilerinden tüketim bilgisinin saklanması ile ilişkili olduğu göstermektedir. Katılımcılar yakın çevrelerinin, daha çok ailelerinin, dikkatini çekmemek ve mahrem alanlarına girmelerini önlemek için alkol tüketimlerini gizlemektedirler. Bunun için de gizli alkol tüketicileri çeşitli saklama stratejileri geliştirmişlerdir. Ailesiyle yaşayan tüketiciler için alkol tüketimi sonrası eve dönmemek, ailenin bulunduğu ortamda alkollü içki tüketmemek, yakınlardaki alkol satan yerlerden alışveriş yapmamak gibi stratejilerdir.

"Minimum risk yaparım. Mesela evin yakınındaki marketlerden asla almam çünkü oradaki kişiler sürekli tanıdıktır ve ailem de sürekli oradaki kişilerden alışveriş yapar, bir şeyler alır ve böylelikle bir şeyler öğrenme şeyleri yüzdesi çok yüksektir. Öyle çok riskli bir durum. Bu yüzden ya evimizin ailemin gitmeyeceği bir yerden alırım ya da arkadaşıma aldırtırım o alkolü...Ya ailemin evde olmadığı bir anı değerlendiririm ya da dışarıda yaparım bu eylemi. Bu riski almam yani buna değmez yani." (A.F., 24).

"Bir sitede oturuyorum ve hani sitemizde de bir küçük market, bakkal tarzı bir market var. Orada da alkol ve tekel gibi bir yer. Mesela akşam uzağa gidemeyeceğim zamanki oturduğumuz yerde çok fazla market yok baya yürümen gerekiyor. Öyle bir şey olmadığı durumlar oraya gitmek geliyor mu aklıma? Geliyor yani ama şöyle bir durum var annem direkt site yöneticisi ve hani şey izole bir insan değil, herkesi tanıyor yani muhtar gibi bir şey sitede. O yüzden oradaki bakkal gibi market gibi yeri işleten kadınla da baya iyiler. Şimdi kalkıp oradan alamıyorum." (S.D., 28).

Ailelileriyle beraber yaşayan bekar katılımcılar ev düzeninden sorumlu olmadıklarından alkollü içki satın alımını ve tüketimini çok ev ve ailenin yaşadığı mahalle ortamından uzakta yapmayı ve tüketim sonrası 
bu ortama girmemeyi tercih ederken ev düzeninden de sorumlu olan ve ortamdan ayrılamayan evli katılımcıların ise stratejileri daha detaylıdır. Bu da aile eve geleceği zaman alkollü ürünlerin ve hatta alkol tüketimini belli edebilecek kadeh, bardak vs. gibi ürünlerin saklanması, kokunun gizlenmeye çalışılması şeklinde gerçekleşmektedir. Aşağıdaki alıntı ise daha da ilginçtir; evli çift, ebeveynleri kendilerini ziyaret edeceği zaman alkol tüketimlerinin ifşa olacağı paniği yaşayarak ev düzenlerini değiştirmektedirler.

"Mesela ben evliyim ve ayrı bir evim var. Ailem benim evime geldikleri zaman mesela eşim de tüketiyor alkol ben de tüketiyorum. Mesela bizim işte şaraplarımız biralarımız oluyor mesela onları saklıyoruz hani. Hasbelkader annem görür ya da babam görür diye hani onları saklıyoruz, yerlerini değiştiriyoruz. işte şarap kadehlerimiz mesela yerlerini değiştiriyoruz. Bu bizde mesela bir panik yaratıyor hani onlar geleceği zaman. Görürler mi hani şey yaparlar mı tepki verirler mi falan diye." (M.D., 27).

"Olması gereken" benlikle gerçek benlik arasında uyumsuzluk yaşayan katılımcılar, normlar koyan çevre karşısında utanç yaşayacakları içkileri satın alırken ürünlerin daha az dikkat çekmesi için, S.D. (28) ifadesiyle "tabii ki de direkt kasaya yönelip bunları alıp çıkmamakta", önce bunları gizlemekte veya başka ürünler de alarak satın alımlarını maskelemektedirler (Nicholas vd., 2015). Maskeleme eylemi yalnızca başka ürünler ekleyerek değil, aynı zamanda da alkollü içkileri çağrıştırabilecek paketleme yönteminden, örneğin gazeteye sarılarak poşetlenmesinden kaçınmak suretiyle de gerçekleşebilir. Katılımcılardan 36 yaşındaki A.P. memleketinde siyah poşetin alkol satın alındığını çağrıştırması nedeniyle alkol alacağı zaman yanında başka torba götürdüğünü, torba götürmediyse de aldıklarının alkollü içki olduğunu diğerlerine fark ettirmeyecek başka bir paketleme yöntemi kullanmaya çalıştığını belirtmiştir.

"Memleketime gittiğimde sigarayla birlikte alkol almak istiyorum...Aldıktan sonra da ya bir gizlemesini ya da başka şeyler varmış gibi göstermesine sebebiyet veriyorum yani görünmesini istemiyorum. Gazeteye sarmak, siyah torba. Yani mesela siyah torbada genelde alkol olduğunu herkes bilir. Ben mesela siyah torba tercih etmiyorum. Gazeteyle birlikte farklı bir torba yanımda götürebiliyorum ya da götürmediysem onu temin edebileceğim bir ortamsa onu temin ediyorum yani benim elimde alkol yok. En basiti iki şişe yan yanaysa çarpmaması için arasında herhangi bir şey koyduruyorum yani o sesten de onun ne olduğunu anlayabileceklerini düşünüyorum." (A.P., 36).

Normlara ve standartlara uymayan davranış sosyal ilgiyi çekmektedir (Ashton vd., 2002). Sosyal ilgiyi çekmeden mahremiyetin sürdürülmesi sosyal etkileşimin kontrolünü getirmektedir (Felmlee, 2001; Masur, 2019; Ker ve Kao, 2021). Alkollü içkinin satın alınması ve tüketimi bilgisinin sadece sözel ve davranışsal olarak gizlenmesi değil, daha da ilerisi bu "erdemsiz" davranışı işaret edebilecek ses, görüntü, koku gibi duyusal uyarıcıların dahi saklanmaya çalışıldığı görülmektedir. Bu sayede tüketici mahremiyetini "minimum risk"le koruyabilmektedir.

\subsection{Anın Tadını Çıkar(ama)mak: Gizliliğin, Tüketicinin Tüketim Pratiklerine Etkisi}

Gizlilikte zihin meşguliyeti modeline (Lane ve Wagner, 1995) göre insanlar bir bilgiyi sakladıklarında ya da zihinlerinde bastırdıklarında gizlenen bilgi tekrarlı olarak akla gelmekte ve tekrarlı olarak bastırılmaktadır. Düşünce istilası sonucunda zihin sürekli olarak sırla meşgul olmaktadır. Rodas ve John (2020) da zihnin meşguliyeti sonucunda gizli tutulan nesne ya da konu ile ilgili değerlendirme ya da durumların daha da sertleştiğini öne sürmüşlerdir. Zihinsel meşguliyet nedeniyle tutumların kutuplaşması olarak isimlendirdikleri olguya göre tüketim pratiklerindeki gizlilik ürün ya da eyleme ilişkin pozitif olan tutum ve değerlendirmelerin, gizliliğin olmadı̆̆ı bir ortamdakine kıyasla daha pozitif, negatif olanların da daha negatif olmasına neden olmaktadır.

Alkol tüketiminin yakın çevreden sert tüketim normları nedeniyle saklanması düşüncelerin alkol tüketimine daha fazla takılmasına neden olmaktadır. Alkol tüketimi ne kadar keyif de verse zihnin takıldığı nokta alkol tüketiminin ifşa olması neticesinde gelebilecek olumsuz sosyal tepkiler (Yang vd., 2018) olmakta ve tüketici tüketim sürecinde stres, korku, kaygı ve endişe yaşamaktadır. Aşağıdaki alıntılar, katılımcılar diğerlerinin davranışsal tepkilerinden ve utanç verici durumdan kaçınmak için gizli tuttukları bilgiler nedeniyle zihinsel meşguliyet yaşadığını ve bu meşguliyetin tüketimden memnuniyeti azalttığını göstermektedir. 
"Mesela oturdum masaya alkol tüketiyoruz ve bunu ailemden gizli yaptığımı düşünmemeye çalışıyorum o an için. Çünkü o an arkadaşlarımlayım. $O$ anın tadını çıkarmaya çalışıyorum ama düşünmemeye çalıştığım sırada da daha fazla düşünmeye itiyor bu beni. Sürekli bir korku bir stres yer alıyor. Sürekli kafamda bu şeyler dönmeye devam ediyor ve alkol tükettikten sonra daha çok bu korku bastırmaya başlıyor... biri görmüş müdür veya üzerimde hala alkolün etkisi var mı, kokusu var mı gibi şeyler düşünüyorum sürekli bu bilgi kafamda olduğu için daha az keyif alıyorum alkol tüketiminden." (A.F., 24).

"Bana bir haz vermesini geçtim daha fazla içmeye yöneltiyor. Bu var yani gerçekten anlayana kadar içiyorum bir yerden sonra ama dediğim gibi bana bir gizlilik işte ailemden saklayarak çıkmışım evden bu bana bir haz vermiyor. Üstüne üstlük yaşadığım bu gerginlik, etkisini azaltıyor yani daha canım sıkkın oluyor çok da hazlı olmuyor bence. Hatta haz vermesinin yanında bence daha kötü bir etkisi oluyor daha fazla içmeme neden olabiliyor." (S.D., 28).

Ancak Rodas ve John (2020)'un önermesinden farklı olarak, mevcut çalışmadaki bulgular artan zihinsel meşguliyetin alkollü içki tüketiminden alınan hazzı zayıflattığını göstermektedir. Çalışmalar arasındaki önemli farklılık, Rodas ve John (2020)'un araştırma bağlamının kadınların gizli çikolata tüketimi iken mevcut çalışmanın Türkiye'de erdemsiz bir ürün kabul edilen alkollü içki tüketimine odaklanmasıdır. Gizli tüketim, daha önce de ifade edildiği gibi tüketicinin kendini ifşa etmeyi (self-disclosure) kontrol ederek tüketim bilgilerini mahrem alanda gizli tutma (Masur, 2019) durumunda da söz konusu olmaktadır. Oysa mevcut çalışmada alkol tüketiminin ötekilerden gizli tutulması söz konusudur. Zihnin "olması gereken"den uzak tutulmaya çalışııması, hissedilen sosyal baskının artmasına neden olmaktadır. Ayrıca tüketimden alınan hazzın zayıflamasının tüketim süreci sırasında ve sonrasında gerçekleşmesi üzerinde durulması gereken bir noktadır. Ortamda ötekiler bizzat olmasa da çevrenin tüketim normlarının var olmaya devam etmesi normatif benlik ile gerçek benlik arasında benlik uyuşmazlığı yaratmaktadır. Dolayısıyla bir yandan yakalanma korkusunun diğer yandan da bilgiyi gizli tutmanın yarattığı gerginlik ve kaygının tüketimden alınan hazzı azalttığı görülmektedir. Olumsuz sosyal tepki beklentisinin olumsuz duygular, tüketimde suçluluk duygusunu ortaya çıkararak (Vangelisti, 1994; Özhan Dedeoğlu ve Kazançoğlu, 2010) bireylere yük taşıma hissi oluşturmaktadır. Gizli alkol tüketiminden suçluluk duyan bireyler vicdanen rahatsı olmakta bundan dolayı da tüketim sürecinde ve sonrasında aldıkları haz azalmakta ve hatta bazen yok olmaktadır.

\subsection{Erdemsiz Tüketimin Sonuçlarını Gizlemek: "Alkolle Bir Paket: Naneli Sakız"}

Çalışmanın bulguları, katılımcıların alkollü içki satın aldıkları ve tükettikleri bilgisi ile birlikte tüketim sürecini ve süreç sonrasında da alkol tüketilmiş olduğunu işaret edecek her türlü bilgiyi sakladıklarına işaret etmektedir. Kullanılan stratejilerden olan maskeleme sadece satın alma sürecinde alkollü ürünleri diğer ürünler arasında dikkat çekmez hale getirme değil, tüketimin sonuçlarını saklayarak sosyal ilgiden kurtulmak için de kullanılmaktadır. Alkollü içki tüketimi sonrası oluşan kokuyu bastırmak için daha yoğun kokulu ürünler tüketerek tüketimin çevre tarafından algılanabilir sonuçları maskelenmeye çalışılmaktadır. Bu çözüm, gizli alkol tüketiminin olmazsa olmaz bir parçası (ve hatta M.Ö’ye göre bir zorunluluk) haline gelmiştir. Koku geçişini sağlamak için sakızdan şekere, kahveden parfüme ve hatta çorba içmeye kadar tüketime konu çeşitli eylemler gerçekleştirilmektedir. En çok tercih edilen ise nane ya da mentollü sakız ve şeker tüketmek olsa da sarımsaklı çorba ya da kahve içmek ve hatta parfüm sıkmak da tercih edilebilmektedir. Koku geçişi eylemine neden olan faktör ise yine istenmeyen sosyal ilgiden kaçınmadır.

"Dışarda alkol tüketeceksek sakız satın almak zorundaydım. Vivident ekstranın özel bir aroması vardı kulaklarından bile alev gibi nane fışkırırdı cayır cayır yakardı insanı. Çok çok kuvvetli bir aroması olan bir sakızdı. Ondan alırdık arkadaşlarla eve giderken. ikişer üçer tane ağzımıza atardık. Kokuyu kesmesi gerekiyor bir şeyin. Alkol kokusunu. Mesela biz Tuborg Gold alırdık yanılmıyorsam o zamanlar. Çünkü Efes daha çok kokuyordu ağız kokusu yapıyordu. Ya da bize öyle geliyordu. Sakız mesela benim için alkolle bir paketti." (M.Ö., 29).

"Alkol tüketirken daha sonrasında onu nasıl bastırabilirim diye düşünüyorum. Mutlaka yanımda parfüm ya da sakız gibi yan ürünler bulundururum. Bazen biraz fazla içip bunların yeterli gelmeyeceğini düşündügüm zamanlarda kahve içerim. Parfüm sıkmak ayrıca önemli çünkü alkol kokusu üstüne de siniyor. Yani mutlaka alkol kokusunu izole edecek şeyler yaparım." (H.Ö., 30). 
"Her zaman sakızım yanımdadır. Olmadı bir naneli şeker bir kokulu şeker bir şeyler alırım. Alkol kokusu yüz metreden alınıyor. Onu bastırmak lazım. Çok içtiğin zamanlar olur. O zaman da sakız, şeker bastırmaz o kokuyu, bol sarımsaklı kelle paça acayip iyi gider. Çok da işe yarar." (T.D., 34).

\section{Sonuç}

Tüketicinin mahremiyeti ya kendisini ifşa etme ya da ötekilerin tüketicinin mahrem alanına girmesi durumunda ortadan kalkmaktadır. Bir bilgiyi ortamdan çıkarmak, başkalarının bilmesini engellemek ve mahremiyeti korumak amacıyla bilinçli bir şekilde saklamak gizliliğin temelini oluşturmaktadır. Gerek mahremiyeti sağlama gerekse sosyal ilgiden kaçınarak sosyal çevreye uyum sağlama ve ideal veya normatif benlik ile gerçek benlik arasındaki uyuşmazlıktan kaçınma çabalarının yönlendirdiği gizliliğin tüketim pratiklerine yansıması, ürünün özelliğine ve tüketim pratiklerini etkileyen sosyal ve kültürel çevresi bağlamına göre farklı gerçekleşebilmektedir. Mevcut çalışma, gizli tüketim olgusunu erdemsiz ürün olarak nitelenen alkollü içki tüketimi odağında incelemekte olup gizliliğin nedenleri, satın alma ve tüketim pratiklerinde nasıl deneyimlendiği ve tüketicinin davranışlarına etkilerini keşfetmek amacıyla gerçekleştirilmiştir. Araştırma bağlamı baskın olarak Müslüman olan Türk toplumunda, diğer illere kıyasla görece daha "açık" bir toplum olarak nitelenen İzmir ilidir. Genç ve eğitimli tüketicilerle gerçekleştirilmiş olan nitel araştırma bulguları, her ne kadar toleranslı olarak nitelense de İzmir ilinde yaşayan eğitimli katılımcıların tüketimde gizliliği zorunluluk düzeyinde bir ihtiyaç olarak deneyimlediğini göstermektedir. Gizli alkol tüketiminin nedenleri bazen sadece basit bir şekilde diğerlerine uyum sağlamak, istemediği sosyal ilgiden kaçınmak, kendi sosyal pozisyonunu korumak iken, sert tüketim normlarının söz konusu olduğu durumda çevre tarafından yargılanmak ve dışlanmak istememek olarak bulunmuştur. İzmir bağlamında genel olarak toplumdan değil de yakın çevreden saklı tutulan bilgi "kötü yola düşürecek" düzeyde erdemsiz olan alkollü içki tüketimidir.

Gizlilik, sadece ürün kullanımı bilgisinin değil, tüketim süreçleri ve sonuçlarına ilişkin bilgilerin ortamdan çıkarılması şeklinde gerçekleşmektedir. Aileleriyle beraber yaşayan bekar katılımcılar alkollü içki satın alımını ve tüketimini çok ev ve mahalle ortamından uzakta yapmayı ve tüketim sonrası bu ortama girmemeyi tercih ederken evli katılımcıların ise stratejileri daha detaylıdır. Satın alma ve tüketim bilgisinin sadece sözel ve davranışsal olarak gizlenmesi değil, bunu işaret edebilecek ses, görüntü, koku gibi duyusal uyarıııların dahi saklandığı veya maskelendiği bulunmuştur. Çevrenin olumsuz tutumu nedeniyle gizli alkol tüketimi, tüketicinin düşüncelerin alkol tüketimine daha fazla takılmasına neden olmaktadır. Zihinsel meşguliyet, sert tüketim normları yükü altında ezilen tüketicinin tüketimden aldığı hazzı azaltmaktadır.

Bu araştırmayla akademik perspektifte tüketici davranışları alanında tüketim pratikleri üzerine henüz çok çalışılmamış yeni bir konu olan tüketimde gizlilik etkisi alkollü içeceklerin gizli tüketilmesi bağlamında ele alınmıştır. Bu bağlamda gizli alkol tüketimi motivasyonlarıyla birlikte gizli alkol tüketiminin tüketici davranışlarına etkileri ortaya konulmuştur.

Keşif amaçlı mevcut çalışma, gizli tüketim olgusunu erdemsiz bir ürün temelinde incelemekte olup, gizli tüketim ile ilgili gelecek araştırmalar erdemli ürünler ile ilgili yapılabilir. Ayrıca özellikle alkollü ürünlerin gizli tüketiminde en önemli değişkenlerden biri olan yakın çevre ve aile etkileşiminin daha da derinlemesine anlaşılması için yeni çalışmalar yapılması da mümkündür. Ürün bağlamı olduğu kadar sosyal ve kültürel bağlama göre de farklılaşabilen gizli tüketim olgusu, farklı sosyal çevrelerde ya da kültürlerde de nitel ve/veya nicel araştırma yöntemleri kullanılarak araştırılabilir. Diğer yandan, bu çalışma gizli alkol tüketiminin yaygınlığını ölçme amacı taşımadığı gibi, erdemsiz ürünlerde gizli tüketimin derin anlaşııması için amaçlı örnekleme ile yapılan çalışmanın bulguları İmir'de yaşayan genç ve eğitimli tüm tüketicilere de genellenemez.

Her ne kadar tüketimi keyif verici olsa da sorumlu tüketilmediğinde gerek tüketicinin kendisinin gerekse toplumun sosyal, psikolojik ve hatta fiziksel iyi oluşuna olumsuz etkisi açık olan alkollü içki tüketiminde gizliliği ve altında yatan motivasyonları anlama, alkol bağımlılığı gibi sorunları yönetme açısından da önem taşımaktadır. Çalışmanın bulguları, sorumlu tüketimi teşvik ederek tüketicinin tüketimden aldığı tatmini artırmak isteyen üretici ve pazarlamacıların gizli tüketim olgusuna ilişkin derinlemesine anlamaları ve içgörüye dayalı pazarlama stratejilerinin geliştirmelerinde de faydalı görülebilir. 


\section{Beyan ve Açıklamalar (Declarations and Disclosures)}

Yazarların Etik Sorumlulukları (Ethical Responsibilities of Authors): Bu çalışmanın yazarları, araştırma ve yayın etiği ilkelerine uyduklarını kabul etmektedirler.

Çıkar Çatışması (Conflicts of Interest): Yazarlar tarafından herhangi bir çıkar çatışması beyan edilmemiştir.

Finansal Destek (Funding): Yazarlar, çalışmanın hazırlanması ve/veya yayınlanması sürecinde herhangi bir finansal destek almamışlardır.

Yazar Katkı Oranı (Author Contributions): Yazarlar, çalışmaya olan katkılarını şu şekilde beyan etmişlerdir: Kavramlaştırma ve çalışma dizaynı, A. Özhan Dedeoğlu; verilerin toplanması, D. Başaran; verilerin analizi ve sonuçların yorumlanması, D. Başaran ve A. Özhan Dedeoğlu; çalışmanın ilk/taslak halinin yazılması, D. Başaran ve A. Özhan Dedeoğlu; çalışmanın gözden geçirilmesi ve düzenlenmesi/düzeltilmesi, D. Başaran ve A. Özhan Dedeoğlu. Çalışmanın ilk ve son hali tüm yazarlar tarafından okunmuş ve onaylanmış olup, yazarlar çalışmalarıyla ilgili sorumluluğu kabul etmektedirler.

Intihal Denetimi (Plagiarism Checking): Bu çalışma, intihal tarama programı kullanılarak intihal taramasından geçirilmiştir.

\section{Kaynaklar}

Ashton, M. C., Lee, K., \& Paunonen, S. V. (2002). What is the central feature of extraversion? Social attention versus reward sensitivity. Journal of Personality and Social Psychology, 83(1), 245-252.

Balestrino, A. (2008). Richard Musgrave and his band of merit goods. History of Economic Ideas, 16(3), 17-19.

Blair, S., \& Roese, N. J. (2013). Balancing the basket: The role of shopping basket composition in embarrassment. Journal of Consumer Research, 40(4), 676-691.

Creswell, J. W., \& Poth, N. C. (2018). Qualitative inquiry \& research design (4. baskı). Londra: Sage Publications.

Critcher, C. R., \& Ferguson, M. J. (2014). The cost of keeping it hidden: Decomposing concealment reveals what makes it depleting. Journal of Experimental Psychology: General, 143(2), 721-735.

Daymon, C., \& Holloway, I. (2002). Qualitative research methods in public relations and marketing communications. USA: Routledge.

Dongjin, H., Jiang, Y., \& Gorn, G. J. (2018). Secrecy prompts nonconformity-avoidance in consumption choice. (Ed.) A. Gershoff, R. Kozinets, \& T. White, NA - Advances in consumer research (46) (pp. 144-145). Duluth, MN: Association for Consumer Research.

Erman, T. (1998). Becoming "urban" or remaining "rural": The views of Turkish rural-to-urban migrants on the "integration" question. International Journal of Middle East Studies, 30(4), 541-561.

Felmlee, D. H. (2001). No couple is an Island: A social network perspective on dyadic stability. Social Forces, 79(4), 12591287.

Fournier, S. (1998). Consumers and their brands: Developing relationship theory in consumer research. Journal of Consumer Research, 24(4), 343-373

Freud, S. (2021). Totem ve tabu (çev. Yılmazer, Z. A.). İstanbul: Türkiye İ̧̧ Bankası Kültür Yayınları.

Gavison, R. (1980). Privacy and the limits of law. The Yale Law Journal, 89(3), 421-471.

Geçtan, E., (2020). insan olmak. ìstanbul: Metis Yayınları.

Goffman, E. (1963). Stigma. Notes on the management of spoiled identity. New York: Simon and Schuster.

Goodwin, C. (1992). A conceptualization of motives to seek privacy for nondeviant consumption. Journal of Consumer Psychology, 1(3), 261-284.

Gullo, K., Brick, D. J., \& Fitzsimons, G. J. (2018). Secret consumption in close relationships. (Ed.) A. Gershoff, R. Kozinets, \& T. White, NA - Advances in consumer research (46) (pp. 145-146). Duluth, MN: Association for Consumer Research.

Heijnders, M., \& Van Der Meij, S. (2006). The fight against stigma: An overview of stigma-reduction strategies and interventions. Psychology, Health \& Medicine, 11(3), 353-363.

Higgins, E. T. (1987). Self-discrepancy: A theory relating self and affect. Psychological Review, 94(3), 319-340.

Higgins, E. T. (1989). Self-discrepancy theory: What patterns of self-beliefs cause people to suffer? Advances in Experimental Social Psychology, 22, 93-136. 
Jensen, K. B. (2002). The complementarity of qualitative and quantitative methodologies in media and communication research. (Ed.) K. B. Jensen, Handbook of media and communications research: Qualitative and quantitative research methodologies (pp. 254-272). USA: Routledge.

Kandiyoti, D. (2016). Locating the politics of gender: Patriarchy, neo-liberal governance and violence in Turkey. Research and Policy on Turkey, 1(2), 103-118.

Kandiyoti, D. (2002). Introduction: Reading the fragments. (Ed.) D. Kandiyoti \& A. Saktanber, Fragments of culture: The everyday of modern Turkey (pp. 1-21). London: I.B. Tauris\&Co. Ltd.

Kelly, A. E. (2002). The Psychology of secrets. New York: Springer Science \& Business Media.

Ker, W. Y., \& Kao, D. T. (2021). Give me perfection or nothing!: The impact of perfectionism on product evaluation as moderated by secrecy effect and name volatility. Journal of Consumer Behaviour, 1-12.

Krishna, A., Herd, K. B., \& Aydınoğlu, N. Z. (2019). A review of consumer embarrassment as a public and private emotion. Journal of Consumer Psychology, 29(3), 492-516.

Lane, J. D., \& Wegner, D. M. (1995). The cognitive consequences of secrecy. Journal of Personality and Social Psychology, 69(2), 237.

Larson, D. G., \& Chastain, R. L. (1990). Self-concealment: Conceptualization, measurement, and health implications. Journal of Social and Clinical psychology, 9(4), 439-455.

Mann, S. (2006). Merit goods in a utilitarian framework. Review of Political Economy, 18(4), 509-520.

Masur, P. K. (2019). Theories of privacy. (Ed.) P. K. Masur, Situational privacy and self-disclosure (pp. 33-68). Springer.

Margulis, S. T. (2003). Privacy as a social issue and behavioral concept. Journal of Social Issues, 59(2), $243-261$.

Nichols, B. S., Raska, D., \& Flint, D. J. (2015). Effects of consumer embarrassment on shopping basket size and value: A study of the millennial consumer. Journal of Consumer Behaviour, 14(1), 41-56.

Özhan Dedeoğlu, A., \& Kazançoğlu, í. (2010). The feelings of consumer guilt: A phenomenological exploration. Journal of Business Economics and Management, 11(3), 462-482.

Pettigrew, S. (2001). The role of alcohol in non-indigenous Australian culture: An ethnographic study. (Ed.) P. M. Tidwell \& T. E. Muller, AP - Asia Pacific advances in consumer research (4). UT: Association for Consumer Research.

Rodas, M. A., \& John, D. R. (2020). The secrecy effect: Secret consumption increases women's product evaluations and choice. Journal of Consumer Research, 46(6), 1093-1109.

Rotenberg, M. (1974). Self-labelling: A missing link in the 'societal reaction' theory of deviance. The Sociological Review, 22(3), 335-354.

Sandıkçı, Ö., \& Ger, G. (2002). In-between modernities and postmodernities: Theorizing Turkish consumptionscape. (Ed.) S. M. Broniarczyk \& K. Nakamoto, NA - Advances in consumer research (29) (pp. 465-470). Valdosta, GA: Association for Consumer Research.

Slepian, M. L., Masicampo, E. J., Toosi, N. R., \& Ambady, N. (2012). The physical burdens of secrecy. Journal of Experimental Psychology: General, 141(4), 619-624.

Slepian, M. L., Camp, N. P., \& Masicampo, E. J. (2015). Exploring the secrecy burden: Secrets, preoccupation, and perceptual judgments. Journal of Experimental Psychology: General, 144(2), e31-e42.

Slepian, M. L., Chun, J. S., \& Mason, M. F. (2017). The experience of secrecy. Journal of Personality and Social Psychology, 113(1), 1-33.

Tajfel, H. (1974). Social identity and intergroup behaviour. Social Science Information, 13(2), 65-93.

Tajfel, H., \& Turner, J. C. (1979). An integrative theory of intergroup conflict. (Ed.) W. G. Austin \& S. Worchel, The social psychology of intergroup relations (pp. 33-47). USA: Brooks/Cole.

Tangney, J. P. (1999). The self-conscious emotions: Shame, guilt, embarrassment and pride. (Ed.) T. Dalgleish \& M. J. Power, Handbook of cognition and emotion (pp. 541-568).

Thomas, V. L., Jewell, R. D., \& Johnson, J. W. (2015). Hidden consumption behaviour: An alternative response to social group influence. European Journal of Marketing, 49(3/4), 512-531.

Thomas, V. L., \& Jewell, R. D. (2019). I can't get you out of my head: The influence of secrecy on consumers' self-brand connections. Journal of Consumer Psychology, 29(3), 463-471.

Thomas, V. L., Johnson, J. W., \& Jewell, R. D. (2016). The tangled web we weave: Deceptive consumption behaviors as a means to cope with identity threat. Marketing Theory, 16(4), 493-512. 
Vangelisti, A. L. (1994). Family secrets: Forms, functions and correlates. Journal of Social and Personal Relationships, 11(1), 113-135.

Ver Eecke, W. (1998). The concept of a "merit good" the ethical dimension in economic theory and the history of economic thought or the transformation of economics into socio-economics. The Journal of Socio-Economics, 27(1), 133-153.

Vrij, A., Paterson, B., Nunkoosing, K., Soukara, S., \& Oosterwegel, A. (2003). Perceived advantages and disadvantages of secrets disclosure. Personality and Individual Differences, 35(3), 593-602.

Wundt, W. (2003). Outline of psychology (Trans. C. H. Judd). Williams \& Norgate G. E. Stechert \& Co.

Yang, X., Deng, X. \& Jia, L. (2018). "A tale of two secrets": Examining the diverging effects of secrecy on consumption enjoyment. (Ed.) A. Gershoff, R.t Kozinets, \& T. White, NA - Advances in consumer research (46) (pp. 146-147). Duluth, MN: Association for Consumer Research.

Yaraman, A. (2018). "Modern Izmir" Pastişi. Cemil Meriç 10.Uluslararası Sosyal Bilimler ve Spor Kongresi. 23-25 Kasım 2018, Hatay/Türkiye. 
This Page Intentionally Left Blank 